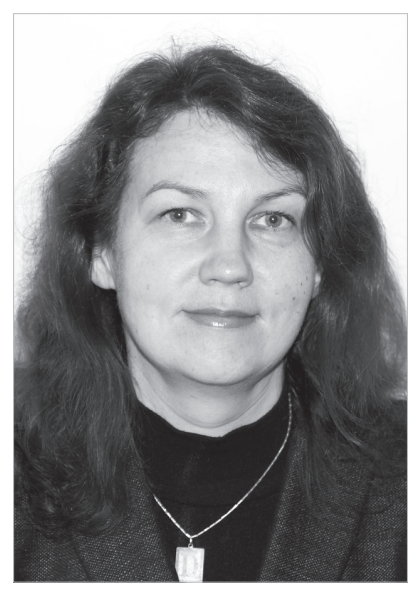

\section{Dalia Gedzevičienè}

Lietuvos teisés institutas
Dalia Gedzevičienè - humanitarinių mokslų daktarè, Lietuvos teisès instituto Leidybos ir bendrųju reikalų skyriaus mokslo darbuotoja, redaktorè.

Moksliniai interesai: kognityvinè lingvistika, metaforų tyrimai, mokslo darbų kalbos ir stiliaus normos.

Adresas: Ankštoji g. 1A, LT-01109 Vilnius, Lietuva.

Tel. $+370 \sim 61267132$.

El.paštas: daliacern@yahoo.com.

Dalia Gedzevičienè: Ph. D. in Humanities, research fellow, editor of Department of Publishing and Management, Law Institute of Lithuania.

Research interests: cognitive linguistics, metaphor research, standard language norms of academic written language. Address: Ankštoji str. 1A, LT-01109 Vilnius, Lithuania. Phone: $+370 \sim 61267132$.

E-mail: daliacern@yahoo.com.

\title{
NUSIKALTELIO IR NUSIKALTIMO METAFOROS LIETUVOS VIEŠAJAME KRIMINOLOGINIAME DISKURSE
}

\begin{abstract}
Anotacija
Straipsnyje, remiantis konceptualiosios metaforos samprata, metafora traktuojama kaip mąstymo strategija, kuri kalboje realizuojama metaforiniais pasakymais. Metaforiniai pasakymai, kuriu tikslo sritis - nusikaltèlis ir nusikaltimas, tyrimui rinkti iš 2001-2015 m. dviejuose Lietuvos naujienų portaluose paskelbtų tekstų. Iš metaforinių pasakymų rekonstruoti konceptualiąsias metaforas ir jas tirti aktualu ne tik dèl to, kad jos atspindi visuomenès požiūrị ị tam tikrą fenomeną, bet ir todèl, kad realizuotos populiarių žiniasklaidos priemonių tekstuose jos drauge ir formuoja visuomenès nuomonę, nes metafora yra ne tik tam tikros lingvistinès formos ir konceptualios struktūros, bet ir komunikacinès funkcijos manifestacija.
\end{abstract}

PAGRINDINIAI ŽODŽIAI: kognityvinè lingvistika, konceptualioji metafora, metaforinis pasakymas, viešasis kriminologinis diskursas.

\footnotetext{
Abstract

On the ground of conceptual metaphor conception, metaphor is discussed as thinking strategy, which is implemented in language by metaphorical expressions. Metaphorical expressions for which target domain is criminal and crime were gathered from texts which were published in two Lithuanian news portals in the years 2001-2015. It is important to reconstruct the conceptual metaphors not only because they reflect viewpoint of society regarding certain phenomenon, but also because implemented in the texts of media influ-
} 
ence on the public opinion, inasmuch as the metaphor is not only some linguistic form and conceptual structure, but also manifestation of communicational function.

KEY WORDS: cognitive linguistics, conceptual metaphor, metaphorical expression, public criminological discourse.

DOI: http://dx.doi.org/10.15181/rh.v19i0.1325

Itvadas

Kognityvinès lingvistikos ir psichologijos mokslu suformuota konceptualiosios metaforos samprata atvère naujų galimybių tiriant įvairiausio pobūdžio diskursus. Metafora vienu metu tapo ir diskurso analizès objek$\mathrm{tu}$, ir jos priemone. Kognityvistai pabrèžè, kad metafora pirmiausia yra ne kalbos, o mąstymo reiškinys. Kalba tik atspindi metaforinių konceptų sistemą, kuri struktūruoja mūsų mąstymą ir veiklą (Lakoff, Johnson 1980, 3-4). Metaforinių konceptų išraiška kalboje yra metaforiniai pasakymai. Konkrečiame diskurse vyraujančios konceptualiosios metaforos atspindi diskurso dalyvių sąmoneje susiformavusį pasaulio vaizdą ir vertybines nuostatas, kurias, pasitelkus tą pati metaforos principą, bandoma įteigti ir diskurso adresatui, nes metaforos lingvistine forma yra ekspresyvi ir įtaigi retorinė priemonẻ išreikšti jos turinị, idèją ir paveikti adresatą, pasiūlyti jam kitą tam tikro dalyko matymo, suvokimo perspektyvą.

Pastaraisiais dešimtmečiais metaforu tyrimuose daug dèmesio skirta konceptualiosios metaforos vaidmeniui socialiniame gyvenime ir socialinejje politikoje. Šiame straipsnyje taip pat tiriamos vieną iš socialinių reiškinių - nusikaltimus - konceptualizuojančios metaforos, realizuotos Lietuvos viešajame kriminologiniame diskurse per pastaruosius penkiolika metuc (2001-2015), ir jų kalbinè raiška, arba metaforiniai pasakymai.

Kai kalbama ar rašoma apie nusikaltimus, nusikaltèlius ir su nusikalstamumu susijusias problemas, organizuojamas tam tikras kriminologinis diskursas. Skirtingi tekstų apie nusikaltimus organizavimo būdai verčia susimąstyti ir apie skirtingus kriminologinius diskursus. Sociologas, kriminologas Aleksandras Dobryninas išskiria tris kriminologinio diskurso tipus: profesinį (kriminologai, kriminalinės justicijos profesionalai), viešąij (,žmonès iš gatvès“, jų informacija apie socialinius įvykius veikiau remiasi prielaidomis ir stereotipais nei tiksliais duomenimis) ir politini (,gerai informuoti piliečiai“). Pastarajai grupei priskiriami politikai, valstybinių ir nevalstybinių institucijų administratoriai, žurnalistai, intelektualai (Do- 
bryninas 2005, 6-7). Vis dẻlto šiame straipsnyje, visų pirma atsižvelgiant i žodžio viešas semantiką ${ }^{1}$ ir kitus argumentus ${ }^{2}$, laikomasi nuostatos, kad žurnalistų parengti ir per žiniasklaidos priemones paskelbti pranešimai apie nusikaltimus ir nusikaltėlius yra viena reikšmingiausių viešojo kriminologinio diskurso formų, jo ideologijos formuotojų, o žiniasklaida yra viena didžiausių šio diskurso sklaidos priemonių.

Žiniasklaidos pranešimai apie kriminalinio pobūdžio i̇vykius iki šiol išlieka itin paklausi informacinè prekè. Visuomenès narių domėjimasis kriminalinėmis problemomis yra gerai žinomas sociologinis fenomenas. Žmonès apie nusikaltimus nori žinoti daugiau ne vien dèl smalsumo, bet pirmiausia dẻl noro žinoti asmeninio saugumo sąlygas visuomenejje, kurioje gyvena (Dobryninas 2001, 11). Šiuo klausimu egzistuoja pozityvus grižtamasis ryšys tarp žiniasklaidos ir visuomenès. Žmonès nori daugiau žinoti ir žiniasklaida tuo pasirūpina - pateikia šios rūšies informaciją kriminalinių žinių, pasakojimų bei reportažų forma (Dobryninas 2001, 73).

Šio straipsnio uždaviniai - iš viešojo diskurso tekstų apie sunkius nusikaltimus išrinkti metaforinius pasakymus, nustatyti jų vyraujančius kalbinès raiškos tipus ir rekonstruoti konceptualiąsias metaforas. Tyrimo objektas yra metaforos, kuriu tikslo sritis - nusikaltèlis, nusikaltimas ir teisésaugos santykis su nusikaltèliu. Straipsnio tikslas - nustatyti šių metaforų ištaku sritis, jos padètų suprasti, kaip šiuolaikinė Lietuvos visuomenė suvokia ir interpretuoja nusikaltèli ir nusikaltimą bei teisėsaugos santykị su nusikaltèliais. Tiriamoji medžiaga - dviejuose Lietuvos naujienų portaluose (delfi.lt ir lrytas.lt) 2001-2015 m. paskelbti straipsniai, kurių pagrindinè tema - sunkūs smurtiniai nusikaltimai (nužudymai, sunkūs sveikatos sutrikdymai, lytiniai nusikaltimai) ir organizuoti nusikaltimai (prekyba narkotikais, kontrabanda, sukčiavimas ir pan.). Darbe taikyti konceptualiosios analizès ir interpretacijos metodai.

Analizuojamuose straipsniuose nusikaltèlis ir nusikaltimas įvardijami, aprašomi, aiškinami ir teisiami. Visa tai daroma, žvelgiant ị tekstų kalbą, tiek tiesiogiai, tiek metaforiškai. Metaforos principą viešajame diskur-

1 „Dabartinès lietuvių kalbos žodyne“ (2011) nurodytos tokios žodžio viešas, - $a$ reikšmės: 1. visiems skirtas, visuomenès naudojamas: V. kelias. óji biblioteka, valgykla; 2. atviras, neslaptas: $V$. susirinkimas. óji nuomoné.

2 Lietuvos viešuoju diskursu vadinami viešojoje erdveje funkcionuojantys ir visiems Lietuvos gyventojams prieinami tekstai bei jų foną sudarantis kontekstas (Papaurèlytė 2014, 193). 
se galima įvardyti kaip vieną iš parankiausių ir produktyviausių diskurso adresanto pasitelkiamų strategijų formuoti įtaigią, patrauklią ir, be abejo, geriau parduodamą informacinę prekę. Išsiaiškinti ir tirti šiuos metaforinius modelius aktualu ne tik dèl to, kad jie atspindi visuomenès požiūrị ì tam tikrą fenomeną, yra tikrovès dalies interpretacija, bet ir todèl, kad realizuoti populiarių žiniasklaidos priemonių tekstuose jie drauge ir formuoja visuomenès nuomonę tam tikra linkme, nes metafora yra ne tik tam tikros lingvistinès formos ir konceptualios struktūros, bet ir komunikacinès funkcijos manifestacija (Steen 2008). Nesąmoninga, o neretai ir sąmoninga tam tikrų metaforinių modelių aktualizacija viešajame diskurse lemia šių tekstų adresato - visuomenès - nuomonę apie nusikalstamumo padètị šalyje, turi ịtakos bendruomenès pozicijai ir elgsenos modeliui tiek nusikaltimo akivaizdoje, tiek nusikaltimu prevencijos požiūriu, tiek praeityje nusikaltusių asmenu atžvilgiu ir pan. Atitinkami metaforiniai modeliai koduoja tam tikras idejjas, todèl kalbinių diskurso strategijų tyrimas svarbus ir tuo, kad kiti du kriminologinio diskurso tipai - profesinis ir politinis - taip pat nėra visiškai atriboti ir atsiriboję nuo viešojo diskurso reiškiamos ideologijos ir jame įsitvirtinusių stereotipų.

Kad teiginys, jog viešajame kriminologiniame diskurse aktualizuojamos metaforos veikia adresato nuomonę tam tikru klausimu, nėra vien teorinė prielaida, patvirtina užsienio mokslininkų tyrimai. Kognityvinès psichologijos specialistų Leros Boroditsky ir Paulio Thibodeau vienoje JAV aukštojoje mokykloje atlikto psicholingvistinio eksperimento (Thibodeau, McClelland, Boroditsky 2009; Thibodeau, Boroditsky 2011) metu buvo panaudoti du viešajame JAV diskurse įsitvirtinę metaforiniai konceptai: (1) Nusikaltèlis yra (plèšrus) Žvéris, medžiojantis visuomeneje, besislepiantis šešèlyje, tamsoje ir iš ten tykantis savo aukų. Policija šioje metaforinèje schemoje suprantama kaip medžiojanti šị plèšrūną, spendžianti jam spąstus ir besistengianti ji pagauti ir įkalinti; (2) Nusikalstamumas yra (užkrečiama) Liga. Šiuo atveju policijos darbas yra nustatyti problemos priežastis, sustabdyti „infekcijos“ plitimą, nustačius rizikos veiksnius užkirsti kelią ateities protrūkiams.

Eksperimento dalyviams buvo pateiktas nusikalstamumo didejjimo išgalvotame mieste aprašymas, vieniems tas aprašymas buvo struktūruotas pagal pirmąij metaforinį modelį, o kitiems - pagal antrąij. Perskaičiusių aprašymą eksperimento dalyvių buvo paprašyta raštu atsakyti ị klausimus 
apie nusikalstamumą mieste ir pasiūlyti šios problemos sprendimo būdą. Vèliau nustatyta, kad tie, kuriems nusikalstamumo situacija buvo aprašyta kaip mieste siautejjančių plèšrūnų, gerokai dažniau kaip šios problemos sprendimą siūlè griežtinti įstatymus ir bausmes, pastatyti daugiau kalejjimų, pasamdyti daugiau policijos pareigūnų ir pan. Tie, kuriems situacija buvo aprašyta remiantis plintančios užkrečiamos ligos metafora, kaip šios problemos sprendimo būdą dažniau siūlè socialines reformas (sveikatos, švietimo, socialinès rūpybos srityse) ir ragino atkreipti dèmesi i prevenciją, i problemos priežastis ir jas šalinti, akcentavo socialinį darbą bendruomenèje.

Šis eksperimentas dar sykị patvirtino kognityvistų teiginị, kad metafora nėra vien paprasta kalbos puošmena. Metaforos gali turèti įtakos tam, kaip žmonès įsivaizduoja, apmąsto ir savo ruožtu tikisi išspręsti svarbias socialines problemas, ir vienõs ar kitõs metaforos pavartojimas viešajame diskurse kalbant apie tokị socialini reiškinị, kaip nusikaltimai, gali paskatinti žmones nesąmoningai siūlyti ir skirtingus nusikalstamumo problemos sprendimo būdus (Thibodeau, McClelland, Boroditsky 2009, 811).

Dar 1991 m. baudžiamosios teisès profesorius George'as L. Kellingas, išnagrinėjęs nevykusį nusikaltimų serijos tyrimą, pabrèžè struktūruojantį, imperatyvų metaforos vaidmeni profesiniame kriminologiniame diskurse. JAV policija metaforiškai vadinama plona mèlyna linija (angl. thin blue line), taip tarsi įsivaizduojama, kad vienoje pusėje yra nusikaltèliai, kitoje - padorūs gyventojai, o tarp jų - plona mèlyna heroju linija. Tokia metafora tarsi sufleruoja, kad gyventojai nusikaltimo atveju yra pasyvūs stebėtojai (ar net potenciali kliūtis sèkmingai tirti nusikaltimus), liekantys anapus „linijos“, už kurios tik policija kovoja su „velnio pajègomis“ (Kelling 1991). Ši metafora, anot G. L. Kellingo, kai kalboje visiškai įsišaknijo ir prarado pirminį savo vaizdingumą, tapo pavojingais mąstymo spąstais ${ }^{3}$.

Savo darbo (policijos), kaip linijos tarp gyventojų ir nusikaltèlių nutiesimo ir šių dviejų stovyklų atribojimo, suvokimas turejjo itin lemtingų padarinių, anot G. L. Kellingo, kai Bafalo mieste (Niujorko valstijoje) per 15 mėnesių buvo išprievartauta 11 mergaičių. Jau po trečio išprievartavimo atvejo policija turejo daug informacijos apie nusikaltèlio „darbo“ braižą (mergaitès buvo užpuolamos vienos einančios į mokyklą ir t. t.). Vis dèlto, vadovaudamiesi policijos, kaip skiriančiosios linijos, metafora ir visiškai atskirdami gyventojus nuo turimos informacijos, detektyvai ne tik atsisakė gyventojų pagalbos sugaunant nusikaltèlį (neva paskleista informacija gali pakenkti tyrimui), bet ir neįspejjo gyventojų apie tykantị pavojų, nepateikė instrukcijų, kaip elgtis siekiant išvengti nusikaltimo ir pan. 
Lietuvos profesinio kriminologinio diskurso (advokatų kalbų) konceptualiąsias metaforas yra nagrinejjusi Regina Koženiauskienè (2005), o viešasis kriminologinis diskursas šiuo aspektu dar nebuvo tirtas.

\section{„Nusikaltèlis yra Ne žmogus“}

Metaforos struktūra yra dvilypè, kognityvistų ji traktuojama kaip ištaku srities požymiu perkèlimas, priskyrimas tikslo sričiai, tam tikro dalyko, reiškinio supratimas, įsivaizdavimas kitais vaizdiniais. Kognityvinèje metaforos teorijoje linkstama manyti, kad ištakų sritis - tai žinios apie reiškinio ar objekto savybes, kurios žmogui yra pažistamos iš jo fizinès ar kultūrinès patirties, o tikslo sritis dažniausiai yra jusliškai nepatiriamo daikto ar reiškinio konceptas, arba abstrakti sritis (Toleikienė 2013, 153). Kalbant apie nusikaltèli ir nusikaltimą kaip apie metaforos tikslo sriti, negalima visiškai patvirtinti šios teorijos dalies. Pirma, smurtiniai nusikaltimai yra jusliškai, kūniškai patiriami, tai konkrečios, o ne abstrakčios veikos, su konkrečiais padariniais. Antra, pasirenkama ištakų sritis, pvz., kad Nusikaltèlis yra Antgamtine būtybè, yra dar menkiau pažǐstama žmogui nei nusikaltèlis. Veikiausiai tai susiję būtent su čia aptariamo sunkaus nusikaltimo specifika, taip pabrěžiant, kad tiek diskurso adresantui, tiek adresatui, konformistinès pasaulèžiūros atstovams, ryžtis padaryti tokị nusikaltimą, kaip ir ji suvokti, yra labai sunku. Taigi šiomis metaforomis siekiama ne palengvinti reiškinio suvokimą, o pabrèžti jo nesuvokiamumą, prieštaravimą mūsų ịprastinei racionaliai logikai. Nesuvokiamumas ir būtų pagrindinis didžiausio konceptualiųu metaforų grupę vienijančio modelio Nusikaltèlis yra Ne žmogus metaforinio perkèlimo pagrindas, arba motyvacija. Šis modelis apima mažiausiai tris vaizdinius, arba konceptualiąsias metaforas ${ }^{4}$ : Nusikaltèlis yra Žveris; Nusikaltèlis yra Antgamtinè būtybè; $N u$ sikaltèlis yra Žuvis.

Tirtõs žiniasklaidos tekstams būdingi trys straipsnyje aptariamų metaforų kalbinès raiškos tipai: vyrauja (1) tiesioginis ištakų ir tikslo sričiu sutapatinimas, kai ištakų sritis suvokiama labai tiesmukai, todèl tokie pasakymai nèra labai išraiškingi, ekspresyvūs, t. y. tekste įvardijamos ir tikslo, ir ištakų sritys (jei sakinyje tikslo sritis kartais ir neįvardijama, iš straipsnio kon-

4 Sąvoka „metaforinis modelis“ šiame straipsnyje vartojama ne kaip termino „konceptualioji metafora" sinonimas, o kaip sąvoka, vienijanti, apimanti ir įvardijanti tam tikrą susijusių konceptualiųių metaforų grupę. 
teksto ji lengvai numanoma), pavyzdžiui, nagrinejjamą metaforini modeli Nusikaltèlis yra Ne Žmogus pavyko taip tiesmukai įvardytą rasti viename tekste, kur cituojamas teisėsaugos pareigūnas, komentuojantis itin žiaurius nusikaltimus darančio nusikaltėlio elgesị: Tai-jau ne žmogus. Tai-vilkas. Savo aukas jis slepia tvarte po šiaudais... (delfi 2010). Gerokai retesni atvejai, kai ištakų sritis tiesiogiai neịvardijama, o nurodomi tam tikri (2) ištaku srities atributiniai ar predikatiniai požymiai, kurie tekste priskiriami tikslo sričiai. Šie metaforiniai pasakymai yra ekspresyvesni už pirmuosius, palieka skaitytojui interpretacijos laisvę, nes iš įvardijamo požymio reikia atkurti visą ištakų sriti (Gudavičius 2014, 38), taip pat nedažnas yra ir (3) metaforinis palyginimas ${ }^{5}$.

Nusikaltèlis yra Žvèris. Iš minètam modeliui priskiriamų konceptualiųjų metaforų tekstuose apie sunkius smurtinius nusikaltimus dominuoja metafora Nusikaltèlis yra Žvéris. Iš metaforinių pasakymų iškyla plëšraus laukinio žvèries, kuris įsiveržè į žmonių gyvenamą teritoriją ir elgiasi pagal savo „žvėriškas“ taisykles, mums neįprastus elgesio standartus ir kuris šioje bendruomenèje yra nesuvokiamas, nelaukiamas, o svarbiausia - mums pavojingas, vaizdinys. Bene dažniausios leksemos, šiuose tekstuose apibūdinančios ištakų sritị, yra žveris, sužvereiti, žveriškas, žveriškai, žveriškumas. Ši kalbinès raiškos grupè priskiriama pirmajam raiškos būdui (tiesioginis ištakų ir tikslo sričių sutapatinimas), ir nors kartais minimi tik predikatiniai ar atributiniai ištakų srities požymiai, vis dèlto tai skamba gana tiesmukai, nes vyrauja leksemos su šaknimi žvèr- - tiesiogine nuoroda i ištakų sriti, pvz.: Jaunesnysis - Gintaras $^{6}$, kurio moteris iki tol nepažinojo, po šiu jos žodžiu tiesiog sužvèrëjo (delfi 2008). Tarsi mégaudamiesi žudynemis sužvèrëje kauniečiai dar karta grižta prie mirtinai peiliu sužaloto $T . V .<\ldots>$ (lrytas 2012). Sugerovai bandè vyra sustabdyti, tačiau sužvèrëjęs mušeika tik pagrasino susidorosiąs ir su jais, jei šie kam prasitars (lrytas 2009). Laisvéje šio vyro žvériški instinktai greitai atgijo - su draugu $<\ldots>$ jis išžagino 21 metu mergina (lrytas 2013). Prieš penkerius metus žvériškai nužudyta viena šviesiausiu miesto ir šalies asmenybiu - kunigas Ričardas Mikutavičius (delfi 2003). Kirviu motina žveiriškai užkapojẹs kaunietis teisme neatgailavo (lrytas

Viešojo diskurso konceptualiųių metaforų kalbinè raiška tirta remiantis Aloyzo Gudavičiaus (2014) pateikta šios srities metaforinių pasakymų klasifikacija.

6 Čia ir kitur pabraukta autorès - D. G. Pavyzdžiuose taip stengtasi išryškinti visą metaforinị pasakymą - tiek ištakų srities leksemas, tiek tikslo (jei jos tekste įvardijamos). 
2014). Penktadieni po pietu Kauno rajone rastas žvériškai nužudyto 30-mečio A. M. kūnas (lrytas 2013). Reikia suvokti, kokio lygmens žveriškumas turëjo būti, kad jie knaisiodavosi lavonuose, juos perveždavo iš vienos vietos $i$ kita (delfi 2014). Tirdami ṣ̨̌ žiauru nužudyma ne tik teisèsaugininkai, bet ir žmogžudžiu advokatai bandè surasti priežastis, kurios jaunus vyrus pastūméjo tokiam žveriškumui (lrytas 2010).

Kiek rečiau straipsniuose ištakų sritis (žvèries konceptas) neįvardijama, o tik nurodomi tam tikri jos atributiniai ar predikatiniai požymiai, kurie tekstuose priskiriami metaforos tikslo sričiai: pvz., sèlinti, tykoti aukos ir pan. Pavyzdžiui, ištrauka iš vieno straipsnio, kuriame įvairiais metaforiniais pasakymais realizuojama metaforinè nusikaltèlio - žvéries paradigma: Jaunuolis tykojo, kada galès užpulti vis dar nieko nę̨tariančiq pensininkę. Petronèle buvo i jaunaji svečia pasisukusi nugara, kai i jos kūna staiga pasipyle dūriai $\langle\ldots>$ Po to Neimantas nusélino prie miegančio pensininkès sünaus ir $i$ jo kūna peili smeigé per 20 kartu $<\ldots>$. Straipsnio pabaigoje jau tiesmukai reziumuojama: Kai Padovinyje pasklido žinia apie žvèriška nusikaltima, prie Petronèlés namu susirinko būrys kaimo gyventoju (lrytas 2015). Kiti pavyzdžiai: 13-metis žagintojas aukos tykojo parke (lrytas 2001). Iškrypèlis abiturientas Kaune auku tykojo po pamoku (delfi 2012). Paaugliu gauja tykojo auku prie mokyklu (delfi 2008). Patykoti ir apiplèsti prabangiu automobiliu važinèjusia Markevičiūte Čeponis pasiūlè savo ištikimiems parankiniams (delfi 2002).

Metaforinis palyginimas šiuose tekstuose dažniausiai vartojamas ne pačių žurnalistų atpasakojime, o tiesioginejje nusikaltimų aukų, liudininkų ar pareigūnų kalboje, pvz.: „Jie pradëjo laužyti duris, langus, daužyti stiklus, elgtis kaip žverrys", - pasakojo pataisos namu direktorius (delfi 2003).,,Keikdamasis, riaumodamas lyg žvèris jis nustūmè mane ị šona ir užgulè visu svoriu bankomata“, - apie nusikaltèli pasakojo auka (delfi 2007). „Grižęs būdavo kaip žvèris. <...>", - pasakojo sūnaus sumušta moteris (lrytas 2008). „Ir kad tokie žmonès nustotu elgtis kaip žveirys... <...>", - kalbëjo grupès narès (delfi 2012).

Nusikaltèlis yra Antgamtinè būtybè - tai antroji konceptualioji metafora, priklausanti metaforiniam Nusikaltèlis yra Ne žmogus modeliui. Antgamtinė būtybẻ dažniausiai įvardijama kaip monstras, pabaisa, rečiau išsigimèlis. Šiais metaforiniais vaizdiniais, kaip ir žvéries metaforos atveju, akcentuojamas nusikaltèlio logikos nesuvokiamumas, nepateisinamumas 
pagal padaryto nusikaltimo mastą, jo žiaurumą, tarsi siekiama pasakyti, kad žmogus to padaryti negalètų. Žvelgiant ị šios metaforos kalbinę raišką matyti, kad šiuo atveju tekstuose dominuoja ir tikslo, ir ištakų srities įvardijimas ir drauge ju sutapatinimas, pvz.: Pagrindinis organizatorius - tikras monstras. Jis gali meiliai su žmogumi kalbètis, glèbesčiuotis, o netrukus duoti nurodyma ji nužudyti (1rytas 2001). Vietos gyventojai galès atsikvépti-keleta metu šis „, Rèkyvos monstru“ vadinamas žmogus ju neterorizuos (delfi 2007). Klaipédos monstru pramintas vyras masiškai žude ne tik priešus, bet ir saviškius (delfi 2014). Po vienišiaus ir ligonio kauke slèpési ne kaimo keistuolis, o žiaurus žudikas, monstras (lrytas 2014). Dembavos monstrui J. Jakubai-

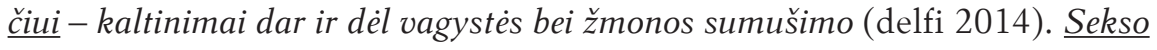
monstras danas tyčiojasi iš Lietuvos (lrytas 2014). Kas broli pavertè bejausmiu pabaisa? Atsakymo ị ši klausima iki šiol ieško kauniete A. P.-M. (lrytas 2015). Deja, ịtarimai nepasitvirtino, išsigimèlis vis dar laisveje (delfi 2014). Rasta ir keletas vaizdingesnių pavyzdžiu, kuriuose kalbama apie nusikaltèlị, nusikaltimo metu tarsi ịgaunantị antgamtinių galių, ar tiesiog nusikaltimams suteikiama tam tikros paslapties, vaiduokliškumo. Šie pavyzdžiai priskirtini antrajam - vaizdingesniam - kalbinès raiškos tipui: Kauniečiu porele savo namuose ịkalino ir pragariškai kankino menininke (delfi 2014). Myriop kauniečius siunčia nematoma ranka (lrytas 2001).

Nusikaltèlis yra Žuvis - trečioji konceptualioji metafora, kurios ištakų sferą apibendrintai būtų galima pavadinti „Ne žmogus“, ji dažniausia diskurse, kurio tema - organizuoti nusikaltimai. Šiems tekstams būdingas toks metaforinis scenarijus - teisėsaugos pareigūnai savo tinklais žvejoja nusikaltèlius - žuvis, kurios vèliau dar išrūšiuojamos į stambias ir smulkias, pvz.: Smulkiosios šio ..verslo" žuvelès - turgaus prekiautoja ir užsakovu nurodymus aklai vykdęs vilkiko vairuotojas (delfi 2010). Belgijos teisésaugos tinkluose - stambus grobis iš Lietuvos $<\ldots>$ Automobiliu vagys buvo teisiami dar 2003-iuju gegužę. Tačiau šie atvykèliai iš Lietuvos buvo tik smulkios žuvelès. Dabar belgai teigia sučiupę ir kelis ryklius (lrytas 2007). Ši tarnyba medžioja tris banginius - grupes ar pavienius asmenis, susijusius su PVM grobstymu, pinigu plovimu ir sukčiavimu ES lëšomis (delfi 2007). Mailiaus milijonu grobstymo afera: i pareigūnu tinklus isivèle stambios žuvys (lrytas 2010). D. Grybauskaite teisésauga ir VMI ragina gaudyti stambias žuvis ir „nenueiti $j$ smulkmenas“ (delfi 2012). STT tinklai - ne stambioms žuvims 
(delfi 2009). Kaip matyti iš pavyzdžių, dažniausias šių metaforų kalbinès raiškos būdas - ištakų ir tikslo sričių sutapatinimas.

„Nusikaltèlis yra (tam tikra) Profesija“

Antrasis produktyvus metaforinis modelis, dominuojantis diskurse apie nužudymus arba sunkius sveikatos sutrikdymus, kurie taip pat neretai baigèsi aukos mirtimi, yra Nusikaltèlis yra (tam tikra) Profesija. Iš esmès tai yra trys profesijos arba užsièmimai, kurių pagrindinè užduotis yra gyvulio ar žmogaus gyvybės nutraukimas: tai - budelis, skerdikas ir medžiotojas. Taigi šiam metaforiniam modeliui priklausytų tokios konceptualiosios metaforos: Nusikaltèlis yra Budelis; Nusikaltèlis yra Skerdikas; Nusikaltèlis yra Medžiotojas. Išvardytos metaforos, ypač Nusikaltèlis yra Budelis ir $\mathrm{Nu}$ sikaltèlis yra Skerdikas, diskurse išskirtinai apibūdina tik žudikus, be to, šios metaforos lemia ir tam tikrą tolesnị metaforinį scenarijų, kai pats šių nusikaltèliu atliktas nusikaltimas irgi atitinkamai metaforizuojamas: Nusikaltimas yra Egzekucija; Nusikaltimas yra Skerdynès; Nusikaltimas yra Medžioklè. Bet būtina patikslinti, kad šie scenarijai išryškejja žvelgiant į visą diskursą, o viename konkrečiame tekste (straipsnyje) ne visuomet laikomasi nuoseklumo, t. y. jei nusikaltèlis vadinamas budeliu, tai ir jo nusikaltimas - egzekucija; tame pačiame tekste neretai chaotiškai realizuojamos kelios konceptualiosios metaforos, pvz., nusikaltèlis vadinamas skerdiku, o jo nusikaltimas - egzekucija, arba nusikaltèlis vadinamas žvėrimi, o jo nusikaltimas - skerdynėmis ir pan. Iš minètam modeliui priklausančių konceptualiųjų metaforų diskurse dažniausiai realizuojamos metaforos Nusikaltèlis yra Budelis ir Nusikaltimas yra Egzekucija, kiek retesnè Nusikaltèlis yra Skerdikas ir Nusikaltimas yra Skerdynes ir gana retos metaforos Nusikaltèlis yra Medžiotojas bei Nusikaltimas yra Medžioklè. Dažniausia šio metaforinio modelio kalbinè raiška - tiesioginis ištakų ir tikslo sričių sutapatinimas.

Nusikaltèlis yra Budelis ir Nusikaltimas yra Egzekucija - tai diskurse produktyviausios minèto modelio konceptualiosios metaforos, pvz.: Verslininko šeimai - mįslinga egzekucija (delfi 2002). Duoklès negave surengè egzekucija (delfi 2003). Kauno teismui perduota žiaurios egzekucijos byla (lrytas 2007). V. Guseliui dar būnant gyvam, prie jo koju egzekutoriai pririšo svarmenis ir įmete $\mathfrak{j}$ upe (lrytas 2008). Automobilio bagažinėje sude- 
gintos septyniolikmetès budeliai išgirdo, ko verti (delfi 2014). Du egzekucijos vykdytojai sulauke griežtų bausmiu (lrytas 2013). Atlikę kruvina darba budeliai neskubèdami patraukia I. Kanto gatves prieigose klientu laukiančiu taksi automobiliu link (lrytas 2012). Egzekucijomis vadinami ir žiaurūs susidorojimai su gyvūnais, pvz.: Šilutès aikštëje - bejegio kačiuko egzekucija (lrytas 2008).

Iš nusikaltimų aprašymų matyti, kad egzekucija įvardijamas itin žiaurus, kankinamas ir ilgiau užtrukęs nužudymas, kuris aukai sukèlė daug skausmo ir kančių, tai išryškẻja iš šiek tiek platesnio šių metaforų konteksto, pvz.: Kankintojai replemis suspaude jam ausị ir norëjo nuplëšti, sparde visi, R. Petrauskas plaktuku daužè rankas ir kojas. <...> D. Bušinsko egzekucija buvo tęsiama garaže Klevu gatvejje (lrytas 2015).

Nusikaltèlis yra Skerdikas; Nusikaltimas yra Skerdynès - šiomis metaforomis dažniausiai nusakomi tokie nužudymai, kai nusikaltimo irankis buvo peilis ar kirvis, tai yra tam tikras metaforinio perkèlimo pagrindas, arba bendrasis dviejų situacijų požymis - nusikaltimo bei ji i̇vykdžiusio nusikaltèlio ir skerdiko bei jo profesijos, jo darbo įrankių, pvz.: Teisèsaugininku žiniomis, kraupiu skerdiku virtęs autoserviso darbuotojas laisvalaikiu medžiojo, todèl savo aukos kūna i gabalus padalijo meistriškai (lrytas 2015). Kauno rajone rastas $\dot{i}$ gabalus supjaustyto vyro kūnas <...> Pareigūnai sulaike ịtariama skerdikq - praeityje du kartus už vagystes teista $<\ldots>$ A. J. (1rytas 2013). Taksistui galva nupjovusị skerdika siūloma ịkalinti 16 metu (lrytas 2010). Skerdynès Margininkuose: nudūręs du brolius V. Zaikinas dar norejo pasimylèti (delfi 2012). Bute buvęs ir skerdynes matęs 3 metu broliukas nenukentëjo (lrytas 2006).

Nusikaltėlis yra Medžiotojas; Nusikaltimas yra Medžioklè - šias konceptualiąsias metaforas galima vadinti periferinemmis konceptualiosiomis metaforomis, nes, lyginant su anksčiau minètomis, šios diskurse nèra itin produktyvios. Taip pat būtina pabrèžti, kad, skirtingai nei jau aptartos metaforos, kaip medžioklè apibūdinami ne vien nužudymai, bet ir lytiniai nusikaltimai, taip pat apskritai aukos sekimas, tykojimas, persekiojimas, kartais ir nesibaigęs nusikaltimo įvykdymu, pvz., kalbama apie anksčiau merginą išprievartavusị lytinị nusikaltèlį: Vèl ištrūkęs iš Pravieniškiu jis privalëjo būti namuose nuo 23 iki 6 valandos, bet šio nurodymo nesilaike ir vèl medžiojo aukas (lrytas 2010). Kauno areštinëje prižiūrètoju dirbęs $\underline{R}$. Gasiulis moteris medžiojo pagal iš anksto parengta plana (lrytas 2010). Žalia- 
kalnio nusikaltèliai pradejo medžioti „Gintarèlį. Bet tada G. Vaičiuli užstojo H. Daktaras ir išgelbëjo ji nuo keršto (lrytas 2002). Visgi dalis pavyzdžių susiję būtent su nužudymais: Prieš trejus metus kraupioje studento medžioklëje ir ji nužudant dalyvave du jauni panevèžiečiai pripažinti kaltais (lrytas 2012). Klaipeddq gasdina išgalvoti žmoniu medžiotojai. < ...> Sklinda gandai apie mieste neva siaučiančius nusikaltèlius, kurie grobia žmones organams (delfi 2011).

Konceptualiosios metaforos Nusikaltèlis yra Medžiotojas ir Nusikaltimas yra Medžiokle tekstuose realizuojamos, kai norima akcentuoti vieną iš medžioklès momentuc - ilgesni aukos sekimą, persekiojimą iki įvykdant nusikaltimą. Šios metaforos atveju tai ir laikytina bendruoju metaforinio perkèlimo požymiu.

Nusikaltimo metaforizavimas

Lietuvos viešajame kriminologiniame diskurse vyrauja trys pagrindinės konceptualiosios metaforos, apibūdinančios sunkų nusikaltimą, tai jau ankstesniame skyriuje aptartos metaforos Nusikaltimas yra Egzekucija; $\mathrm{Nu}$ sikaltimas yra Skerdynès; Nusikaltimas yra Medžioklè. Jomis metaforizuojamas pats nusikaltimo vyksmas, jo vykdymas ir įvykdymas. Dar viena - ketvirtoji - konceptualioji metafora Nusikaltimas yra Žemès drebėjimas metaforizuoja kitą nusikaltimo momentą, tiksliau - žinios, naujienos apie sunkų nusikaltimą pasklidimo efektą. Tokiais atvejais tiesiogiai ištakų sritis diskurse neįvardijama, nurodomas tik jos požymis - gebėjimas sukrėsti, sudrebinti šalị ar miestą, tai metaforiniuose pasakymuose reiškiama predikatiniais žodžiais (veiksmažodžiais), pvz.: Kauno rajone esančia $\underline{\text { Ringaudu }}$ gyvenviete sukrète žiaurus nusikaltimas (lrytas 2006). Ramu Preilos gyvenima sukrètè kraupus nusikaltimas (lrytas 2009). 2009-uju gegužés pabaigoje Lietuva sukrète ypač žiaurus nusikaltimas (1rytas 2010). Mažametès ǐšžaginimo sukrèsta Jonava spèlioja, kas privertè kaimynystëje augusị šešiolikmetị sužverèti (delfi 2014). Turètu paaiškèti Lietuva drebinusiu žmogžudysčiu atstovai (delfi 2010). Diskurse nurodomi predikatiniai požymiai - sukrèsti, sudrebinti šali ar miesta - nusikaltimą konceptualizuoja kaip vieną iš gamtos stichijų - žemės drebėjimą. Taip aktualizuojami ypač sunkaus nusikaltimo žiaurių padarinių ir neiprastumo momentai, lygiai kaip Lietuvoje neįprastas ir retas yra žemès drebejjimas. 
Dar viena nusikaltimus šiame diskurse konceptualizuojanti metafora - Nusikaltimas yra (sunkus materialus) Objektas. Ši metafora dažniausiai nusako nusikaltimą kaip žmogaus praeityje įvykusį faktą, atsiminimą, kitaip tariant, mentalini darini žmogaus sąmonèje - nusikaltimo vaizdinį. Šiuo atveju metaforiniais pasakymais pabrèžiami tam tikri atributiniai ir predikatiniai šio materialaus objekto požymiai - t. y. jo svoris, sunkumas, niekaip kitaip (tiesmukai ar konkrečiai) ištakų sritis diskurse neįvardijama, pvz.: Tačiau pastaraji dabar slegia ne tik automobilio keleivio mirtis, bet ir laukianti akistata su teisésaugos pareigūnais, nes prie vairo jaunuolis sèdo neblaivus ir neturëdamas teisès vairuoti (lrytas 2007). Už grotu laikoma kaunieti slegia vis sunkesne itarimu našta (delfi 2010). Ju są̧žine slegia kraupi nelaime Kauno forte (delfi 2012). Marijampoles gyventojo sqžine turètu slègti net triju žmoniu mirtys (delfi 2015). D. Šatavičius aiškino, kad daugiau negali taip gyventi - jo sažzine slegia nužudymas (delfi 2013). Ši konceptualioji metafora yra realizuota ir kuriant teisės terminus. Visiems žinomi ir ịprasti tokie sudètiniai teisès terminai, kaip sunkus nusikaltimas, nesunkus nusikaltimas, apysunkis nusikaltimas. Šiuo atveju tai yra tik kalbos, arba mirusi, metafora, ja įvardijamas tam tikras nusikaltimo pobūdis, kuris kalboje tiesiog neturi kito įvardijimo. Vis dèlto atkreiptinas dèmesys, jog ir šis metaforinis pasakymas paimtas ir terminologizuotas iš platesnès metaforinès paradigmos, iki šiol gyvos mūsų viešajame diskurse.

Teisésaugos santykis su nusikaltèliais ir jo metaforinè konceptualizacija

Teisėsaugos santykis su nusikaltèliais viešajame diskurse struktūruojamas pasitelkus tris dominuojančias konceptualiąsias metaforas: Teisésaugos santykis su nusikaltéliais yra Medžioklè / Žvejyba / Kova. Matyti, kad tai yra logiška anksčiau aptartų konceptualiųjų metaforų seka, kitaip tariant, diskurse realizuojamas visas tipinis metaforinis scenarijus, pvz.: Nusikaltèlis yra Žveris, o teisėsaugos užduotis yra jị, ịsiveržusị ị žmonių bendruomenę ir jai pavojingą, sumedžioti; arba Nusikaltèlis yra Žuvis, tad teisésaugos darbas yra ją sužvejoti; Nusikaltèlis yra Pabaisa, o teisėsaugos darbas yra su ja kovoti, nukauti, izoliuoti nuo visuomenès.

Teisėsaugos santykis su nusikaltèliais yra Medžioklè, pvz.: Kai teisésaugos kilpa pernai èmé veržtis aplink $H$. Daktarą, šis $\langle\ldots\rangle$ staiga pradingo (delfi 2009). <..> ieškomiausias nusikaltèlis Romas Zamolskis jau 
kuris laikas gyvena Pakauneje. Nors kelis kartus Karmèlavoje ir priemiesčio rajonuose buvo surengtos pasalos, jis išvenge sulaikymo (delfi 2002). Nors policija E. Šmidta ...medžiojo“ labai aktyviai, jam pavykdavo paskutine akimirka pasprukti (delfi 2005). A. Tokeri policija èmé ,,medžioti“ 2004 metais (delfi 2006). Naujo maniako medžioklè prasidejo 2001-uju vasara (delfi 2012). Korumpuotus pareigūnus medžiojantys Kauno policijos Imuniteto poskyrio pareigūnai tyrima pradëjo vos gavę informacija <...> (lrytas 2013). Policija užspeite ir antrq abituriento žudikq (1rytas 2007).

Teisėsaugos santykis su nusikaltèliais yra Žvejyba, pvz.: Nesnaudè ir Lietuvos pareigūnai - i ju tinklus daktaru gaujos nariai pakliüdavo vienas po kito (delfi 2014). Pareigūnai surengè pasala prie Draudeniu ežero ir i aplinkosaugininku ,tinklus“ pakliuvo patys tinklininkai [brakonieriai - aut. past.] (delfi 2012).

Teisėsaugos santykis su nusikaltėliais yra Kova, pvz.: Vilnius su nusikaltèliais kovos vaizdo kameromis (delfi 2000). Prieš organizuota nusikalstamuma Lietuvoje meginama kovoti vidaus pulku įvedimu $j$ miestus, keliu policijai rengiant operacijas „voratinklis“, rengiant kratas (delfi 2001). Lietuva ir Lenkija stiprins kovq su nusikalstamumu pasienyje (delfi 2014). Kova su organizuotu nusikalstamumu Panevėžyje pareikalavo auku (delfi 2008).

Iš esmès ta pati kova skatinama, pageidaujama ir iš visuomenès pusès: Raseiniuose susiklostè palanki dirva, kad žmonès pradètu kovoti su nusikaltèliais (delfi 2003). Karą Biržų banditams paskelbęs ūkininkas $<\ldots>$ Romualdas Misevičius stoja i kova su Biržu rajono nusikaltèliais (delfi 2013).

Kova, kovoti - šie žodžiai yra ir daugybès nacionalinių bei tarptautinių institucijų, organizacijų oficialių pavadinimų sudedamoji dalis.

Šiame straipsnyje aprašyta didžioji dalis žiniasklaidos tekstuose apie sunkius smurtinius ir organizuotus nusikaltimus (nuo 2001 iki 2015 m.) funkcionuojančiu konceptualiųju metaforų. Pirmiausia inventorizuoti, o tuomet ir tirti šias metaforas aktualu ne vien dèl to, kad tai yra bendruomenès požiūrio tam tikru klausimu raiška, mentaliteto atspindys, bet ir todèl, kad šios metaforos, realizuotos viešajame diskurse, formuoja, sąmoningai ar nesąmoningai diktuoja mąstymo, įsivaizdavimo, o drauge - ir veiklos bei elgsenos kryptis.

Pabaigoje hipotetiškai galima svarstyti, ar, pavyzdžiui, tokie Lietuvos viešajame diskurse dominuojantys metaforiniai modeliai kaip Nusikaltèlis yra Ne žmogus, neturi ịtakos baudimo tradicijos formavimuisi, baudžia- 
mosios politikos krypčiai. Ir nors pastarąij dešimtmeti Lietuvoje statistiškai nusikaltimų nedaugeja, anot kriminologų, baudžiamasis klimatas Lietuvoje tampa vis atšiauresnis, tai matyti ịvertinus baudžiamųjų ịstatymų leidybos ir baudžiamojo persekiojimo rodiklius (Sakalauskas 2014, 98). Retoriškai galima klausti, ar tokia diskurse produktyvi metafora, kaip Nusikalteilis yra Žveris, nesufleruoja, kodèl pirmiausia kalbama apie nusikaltèlio izoliavima, o profesionalų pasiūlymai dèl, pavyzdžiui, nusikaltusio ir teisto asmens integracijos ị bendruomenę visuomet sukelia didžiulị visuomenès pasipiktinimą. Minètos metaforos atspindi, o toliau vartojamos, ypač žiniasklaidoje, ir įtvirtina įsivaizdavimą, kad visuomenè yra saugi tuomet, kai nusikaltę asmenys yra tiesiog uždaryti. Anot kriminologo Gintauto Sakalausko, visuomenė saugiausia tuomet, kai (ir) teisti asmenys joje gyvena integruotai (Sakalauskas 2015, 39).

Išvados

1. Tiriant 2001-2015 m. Lietuvos viešąij kriminologinį diskursą apie sunkius nusikaltimus nustatyta, kad, kalbant apie nusikaltimą ir nusikaltėlį, dominuoja du dideli, šiuos tekstus struktūruojantys metaforiniai modeliai: Nusikaltèlis yra Ne žmogus (šiai metaforinei paradigmai priskirtinos konceptualiosios metaforos Nusikaltelis yra Žverris, Nusikaltèlis yra Antgamtinè būtybè, Nusikaltèlis yra Žuvis) ir Nusikaltèlis yra (tam tikra) Profesija (budelis, skerdikas, medžiotojas). Nusikaltimas metaforizuojamas trejopai: įvykdytas nusikaltimas (jo vyksmas, įvykdymas) įvardijamas kaip egzekucija, skerdynès arba medžiokle; kai minimas žinios apie sunkų nusikaltimą pasklidimas - nusikaltimas įsivaizduojamas kaip žemès drebëjimas; kai apie nusikaltimą kalbama kaip apie žmogaus praeityje įvykusi faktą, nusikaltimo vaizdini žmogaus sąmonejje - jis regimas kaip sunkus materialus objektas, našta. Teisėsaugos santykis su sunkų nusikaltimą darančiu ar jau padariusiu nusikaltèliu dažniausiai metaforiškai įvardijamas kaip medžiokle, žvejyba arba kova. Didžioji dalis šiu metaforu priklauso tam tikriems metaforiniams scenarijams, kurių realizacija išryškejja ne iš atskiro konkretaus straipsnio, o iš viso diskurso (pvz., nusikaltèlis yra žvèris, tad teisèsaugos pareigūnai turi ji sumedžioti ir pan.). 
2. Dažniausia tirtų metaforų kalbinès raiškos forma yra tiesioginis ištakų ir tikslo sričių sutapatinimas, kai tekste įvardijami ir ištakų, ir tikslo sričiu konceptai bei jie sutapatinami (šiai formai priklauso ir atvejai, kai sakinyje tiesiogiai neįvardijamas tikslo srities subjektas ar objektas, bet iš straipsnio konteksto jis lengvai numanomas). Ši raiškos forma nèra itin išraiškinga ir vaizdinga. Gerokai ekspresyvesni, bet drauge ir retesni viešajame diskurse yra tokie metaforiniai pasakymai, kai ištakų srities konceptas tiesiogiai neįvardijamas, o minimi tik atskiri jo požymiai (predikatiniai ar atributiniai), kurie priskiriami tikslo sričiai. Rečiausia ir išraiškingumo požiūriu mažiausiai ekspresyvi yra trečioji metaforų forma - metaforinis palyginimas, kurio didžioji dauguma pavartojimo atvejų užfiksuota straipsniuose cituojamoje tiesioginejje nusikaltimo aukų, liudytoju ar pareigūnų kalboje.

3. Straipsnyje nurodytos viešajame kriminologiniame diskurse dominuojančios konceptualiosios metaforos ne tik atspindi dabartinès Lietuvos visuomenès požiūrị i̊ nusikaltimą, nusikaltèlį bei teisèsaugos santykị su nusikaltėliu, bet, remiantis užsienio mokslininkų atliktais šios srities eksperimentais, ir ji veikia, drauge darydamos įtaką ir profesiniam bei politiniam kriminologiniams diskursams, nes žiniasklaidos atstovai, tiek nesąmoningai, tiek ir sąmoningai, siekdami sukurti patrauklesnic tekstą, pataikaudami skaitytojams, realizuoja visuomenejje funkcionuojančias metaforas, taip jas dar labiau ịtvirtindami ir suteikdami joms politinių galių.

\section{Literatūra}

Dabartinès lietuvių kalbos žodynas 2011 - Dabartinès lietuvių kalbos žodynas: šeštas (trečias elektroninis) leidimas. Vilnius: Lietuvių kalbos institutas, 2006; internetinė versija, 2011 (http://dz.lki.lt).

Dobryninas 2005 - Aleksandras Dobryninas. Kriminologiniai diskursai. Habilitacijos procedūrai teikiamų mokslinių darbų apžvalga. Socialiniai mokslai, sociologija (05S). Vilnius: Vilniaus universitetas.

Dobryninas 2001 - Aleksandras Dobryninas. Virtuali nusikaltimu tikrové. Vilnius: Eugrimas.

Gudavičius 2014 - Aloyzas Gudavičius. Ištakos srities raiška metaforiniuose pasakymuose. Filologija, 19, 33-47.

Kelling 1991 - George L. Kelling. Crime and Metaphor: Toward a New Concept of Policing. City Journal 1: View Article (http://www.city-journal.org/story.php?id=1577). 
Koženiauskienė 2005 - Regina Koženiauskienė. Konceptualiųių metaforų etinis aspektas advokatu kalbose. Filologija, 10, 52-56.

Lakoff, Johnson 1980 - George Lakoff, Mark Johnson. Metaphors We Live By. Chicago: The University of Chicago Press.

Papaurèlyte 2014 - Silvija Papaurèlytė. Metaforinis karo modelis Lietuvos sveikatos diskurse (1980-2001 m.). Res humanitariae, XVI, 192-212.

Sakalauskas 2015 - Gintautas Sakalauskas. Kalinimo sąlygos ir kalinių resocializacijos prielaidos. Teisès problemos, 2 (88), 5-53.

Sakalauskas 2014 - Gintautas Sakalauskas. Ką liudija didejjantis baudžiamasis represyvumas Lietuvoje? Kriminologijos studijos, 2, 96.

Steen 2008 - Gerard Steen. The Paradox of Metaphor: Why We Need a Three-Dimensional Model of Metaphor. Metaphor and Symbol, 23, 213-241 (https://www.academia. edu/235694/The_paradox_of_metaphor).

Thibodeau, Boroditsky 2011 - Paul H. Thibodeau, Lera Boroditsky. Metaphors We Think With: The Role of Metaphor in Reasoning (http://www.plosone.org/article/ info\%3Adoi\%2F10.1371\%2Fjournal.pone.0016782).

Thibodeau, McClelland, Boroditsky 2009 - Paul H. Thibodeau, James McClelland, Lera Boroditsky. When a bad metaphor may not be a victimless crime: The role of metaphor in social policy. Proceedings of the 31st Annual Conference of the Cognitive Science Society, 809-814.

Toleikienè 2013 - Reda Toleikienè. Metaforos, kuriomis gyvenome Londono olimpiados metu. Filologija, 18, 152-162.

Šaltiniai

delfi - http://www.delfi.lt (2001-2015);

lrytas - http://www.lrytas.lt (2001-2015).

\section{Dalia Gedzevičienè}

\section{METAPHORS OF CRIMINAL AND CRIME IN LITHUANIAN PUBLIC CRIMINOLOGICAL DISCOURSE}

Summary

The one of the most important public criminological discourse forms is media reports about criminal events: first, this is one of the biggest spaces of expression of this discourse, second, this is one of the most important developers of aforementioned discourse ideology. In the analysis of discourse the words used in texts are especially important, if their meanings reflect world view and values formed in the conscience of discourse. Conceptual metaphors analysis was chosen as research method in the pre- 
sent article. On the ground of conceptual metaphor conception formed by cognitive linguistic, metaphor is discussed as thinking strategy, which is implemented in language by metaphorical expressions. Conceptual metaphor is understood as an interaction of two conceptual domains (source and target), when talking and thinking about some things from target domain proceed as talking and thinking about things from source domain.

Metaphorical expressions for which target domain is criminal and crime were gathered for the research from texts which were published in two Lithuanian news portals (delfi.lt, lrytas.lt) in the years 2001-2015. In the centre of attention of this research were articles with the main theme of crimes of violence (killings, serious injuries, sex crimes) and also organised crimes. Later the metaphorical expressions were grouped by the meanings of conceptual metaphors and metaphorical models dominating over the last 15 years in this discourse were specified: CRIMINAL IS AN ANIMAL; CRIMINAL IS A SUPERNATURAL BEING (freak, monster, degenerate); CRIMINAL IS A FISH (this three conceptual metaphors belongs to predominant metaphorical model CRIMINAL IS NOT A HUMAN BEING); CRIMINAL IS AN EXECUTIONER; CRIMINAL IS A SLAUGHTER; CRIMINAL IS A HUNTER (this three conceptual metaphors belongs to predominant metaphorical model CRIMINAL HAS CERTAIN PROFESSION); CRIME IS AN EXECUTION; CRIME IS A SLAUGHTER; CRIME IS A HUNT; CRIME IS AN EARTHQUAKE; CRIME IS A MATERIAL OBJECT; RELATION OF JUSTICE WITH CRIMINALS IS A FIGHT / HUNT / FISHING.

It is important to explore and clarify these metaphorical models not only because they reflect and express viewpoint of society regarding certain phenomenon, because they are interpretation of part of reality, but also because implemented in the texts of popular media they give certain direction to the public opinion, in as much as the metaphor is not only some linguistic form and conceptual structure, but also manifestation of communicational function. Linguistic form of the metaphor is expressive and suggestive rethoric measure which helps to express its content, idea and to affect the narratee, to propose him/her the other perspective of certain thing seeing, perception. Therefore often conscious actualization of some metaphorical models in public discourse influences the opinion of narratee of these texts - of society - regarding crime patterns in the coun- 
try, affects community attitude and behaviour model when faced with the crime, from crime prevention point of view, concerning criminal offenders of the past etc. Certain metaphorical models code certain ideas, therefore research of discourse language strategies is important also, because two other types of criminological discourse - professional and political are not wholly delimited from public discourse' ideology and stereotypes. 